\title{
HORMONAL ASSESSMENT IN ACNE VULGARIS IN WOMEN
}

\author{
T. S. Mohanarao ${ }^{1}$, Chenna Subhashini2, Shaik Asha³, Swetha Naidu4, Anila Sunandini5, Guru Prasad6, Ch. Naveen Kumar7, \\ Chandrasekhar Nalabola ${ }^{8}$
}

${ }^{1}$ Associate Professor, Department of DVL, Andhra Medical College, KGH, Visakhapatnam.
2Assistant Professor, Department of DVL, Andhra Medical College, KGH, Visakhapatnam.
${ }^{3}$ Postgraduate Student, Department of DVL, Andhra Medical College, KGH, Visakhapatnam.
4Postgraduate Student, Department of DVL, Andhra Medical College, KGH, Visakhapatnam.
5Professor, Department of DVL, Andhra Medical College, KGH, Visakhapatnam.
6Professor, Department of DVL, Andhra Medical College, KGH, Visakhapatnam.
7Postgraduate Student, Department of DVL, Andhra Medical College, KGH, Visakhapatnam.
8Postgraduate Student, Department of DVL, Andhra Medical College, KGH, Visakhapatnam.

\section{BACKGROUND}

ABSTRACT

Acne vulgaris is a chronic inflammatory disease of the pilosebaceous unit characterised clinically by non-inflammatory lesions, open and closed comedones and papules or pustules and nodules of varying degree of inflammation and depth, distributed predominantly over face, back and chest. There are various aetiopathogenetic mechanisms and the major pathogenic factors involved are hyperkeratinisation, obstruction of sebaceous follicle resulting from abnormal keratinisation of the infundibular epithelium, stimulation of sebaceous gland secretion by androgens and various hormones and microbial colonisation of pilosebaceous units by P. acnes which promotes perifollicular inflammation. Of note, hormonal therapies are indicated in severe, resistant-to-treatment cases and in those with monthly flare-ups and when standard therapeutic options are inappropriate. So based on grading of acne and duration of lesions and time of presentation, hormonal assessment plays an important role in the management of acne vulgaris.

\section{MATERIALS AND METHODS}

Hormonal evaluation is not mandatory for those who experience short bouts of onset and offset or those who respond well to standard treatments. However, in the more resistant cases and for those who fail to respond to conventional therapies and based on the grading endocrinal evaluation along with investigations- lipid profile, thyroid profile and ultrasound abdomen are important tools in the management of acne vulgaris. However, in our study, 25 female patients aged between 16 - 35 years who failed to respond to novel conventional treatments of acne were selected and subjected to hormonal assessment.

Study Design- This is a descriptive study by assessing various hormonal levels in selected patients.

Study Setting- DVL Department, Andhra Medical College affiliated to King George Hospital, Visakhapatnam, Andhra Pradesh, India.

\section{RESULTS}

Out of 25 patients, 12 patients (48\%) were in the age group between 15 - 20 years with moderate degree of acne with PCOS, 8 patients (32\%) were in the age group between 21 - 25 years, 3 patients (12\%) were in the age group between $26-30$ years and $8 \%$ were between 31 - 35 years, and in our study out of 25 patients $56 \%$ had hypertriglyceridaemia, $20 \%$ with increased free testosterone levels and very few patients with obesity and features of virilisation.

\section{CONCLUSION}

Thus, Hormonal evaluation should not be the last option in treating acne vulgaris and is mandatory not only for more resistant acne cases and for those who fail to respond to conventional therapies, but it also should be done in the beginning even in mild degrees of acne to prevent acne scarring.

\section{KEYWORDS}

DHEA (Dehydroepiandrostenedione), Propionibacterium Acnes, PCOS (Polycystic Ovarian Syndrome), Acne Vulgaris.

HOW TO CITE THIS ARTICLE: Mohanarao TS, Subhashini C, Asha S, et al. Hormonal assessment in acne vulgaris in women. J. Evolution Med. Dent. Sci. 2017;6(94):6834-6836, DOI: 10.14260/jemds/2017/1480

\section{BACKGROUND}

Acne vulgaris is a chronic inflammatory disease of the pilosebaceous unit characterised clinically by

'Financial or Other Competing Interest': None.

Submission 18-11-2017, Peer Review 02-12-2017,

Acceptance 13-12-2017, Published 18-12-2017.

Corresponding Author:

Dr. Chenna Subhashini,

C/o. C. Sudhakar, Flat No. 104 and 105,

Gajanana Apartments, Santhinagar, NAD, Kotha Road,

Visakhapatnam-530009, Andhra Pradesh.

E-mail: chennasubhasubhashini@gmail.com

DOI: $10.14260 /$ jemds $/ 2017 / 1480$

\section{(c) $(1)$}

non-inflammatory lesions, open and closed comedones and papules or pustules and nodules of varying degree of inflammation and depth distributed predominantly over face, back and chest. There are various aetiopathogenetic mechanisms. Acne is a follicular unit disease. It involves pathologically overproduction of serum, abnormal follicular keratinisation, formation of $P$. acnes biofilms and colonies, and finally the release of pro-inflammatory mediators to the skin.1,2,3,4 Acne-prone individuals have larger sized sebaceous glands that are stimulated at the time of puberty. Several pathways and hormones beside androgens regulate the activity of sebocytes. 
A number of agents are secreted by $P$. acnes and include the enzymes lipase and protease that manage to disrupt and degrade the follicular wall and initiate a cascade of inflammatory events and release of chemotactic factors.5,6 The pilosebaceous unit is capable of metabolising and producing pro-vitamin $\mathrm{D}$ in the skin. Vitamin D deficiency may be linked to the pathogenesis of insulin resistance and the metabolic syndrome in polycystic ovary syndrome (PCOS).

\section{Various Hormones Implicated in the Pathogenesis of Acne Vulgaris \\ Androgens}

Individuals with genetic deficiency of androgen receptors have no detectable sebum secretion and therefore there is no development of acne.

DHEAS, regulator of sebaceous gland activity through its conversion to DHT and Testosterone in sebaceous gland by potent enzymes.

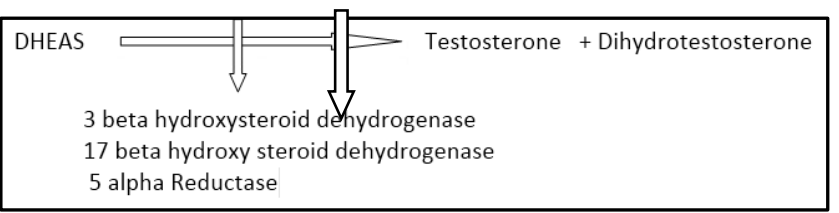

\section{Progesterone}

It inhibits $5 \alpha$-reductase required to convert testosterone to the more potent DHT. Menstrual flare and sebum exacerbations are caused by progesterone whose receptors are expressed in basal epidermal keratinocytes only.

\section{Oestrogen}

High-dose oestrogen exerts a negative feedback on the gonadal axis. This results in the reduction of sebaceous gland size and concomitantly reduced sebum formation.

\section{Pituitary Hormones}

MSH and ACTH, growth hormone and prolactin act directly on sebaceous glands that increases both sebum production and mitosis of sebaceous cells. Androgens are secreted by the ovaries under regulation of $\mathrm{LH}$.

\section{Peroxisome Proliferator-Activated Receptor (PPAR)}

Present in sebocytes are activated in patients receiving fibrates (PPAR-alpha ligands) for hyperlipidaemia and thiazolidinediones taken for Type 2 DM increases sebum production.

\section{Glucocorticosteroids}

Steroids are thought to increase acne eruptions (steroid acne) through their increased toll-like receptor 2 gene expressions and further release of the pro-inflammatory mediators.

\section{Endocrinal Evaluation in Patients with Suspected Hormonal Acne}

Hormonal evaluation is mandatory for those who experience short bouts of onset and offset or even those who respond well to standard treatments. However, in the more resistant cases and for those who fail to respond to conventional therapies, endocrinal evaluation is an important tool to consider as well as in the following cases- Late-onset acne; Therapy-resistant acne; Prepubertal acne; Stress-exacerbated acne; Premenstrual onset; and Hyperandrogenism. Signs of virilisation (Clitiromegaly, deepened voices and masculine features) PCOS; signs of hyperinsulinaemia (Obesity in the trunks, skin tags and acanthosis); distribution of the acne lesions. It is well recognised that hormonal acne concentrates in the lower third of the face along the chin and jaw lines.

\section{MATERIALS AND METHODS}

25 female patients aged between 16 - 35 years who failed to respond to novel conventional treatments of acne were selected and subjected to hormonal assessment based on Global Acne Grading System.

\section{Global Acne Grading System}

\begin{tabular}{|c|c|}
\hline Location of the Acne & Factor \\
\hline Forehead & 2 \\
\hline Right cheek & 2 \\
\hline Left cheek & 2 \\
\hline Nose & 1 \\
\hline Chin & 1 \\
\hline Chest and Upper back & 3 \\
\hline
\end{tabular}

\begin{tabular}{|c|c|}
\hline Severity & Grade \\
\hline Number of lesions & 0 \\
\hline Comedones & 1 \\
\hline Papules & 2 \\
\hline Pustules & 3 \\
\hline Nodules & 4 \\
\hline
\end{tabular}

Local score $=$ Factor $*$ Grade.

\section{Staging}

\begin{tabular}{|c|c|}
\hline Mild & $1-18$ \\
\hline Moderate & $19-30$ \\
\hline Severe & $31-38$ \\
\hline Very Severe & $>39$ \\
\hline
\end{tabular}

Laboratory Tests to be done in a Patient with different Grades of Acne Includes

1. Serum Free Testosterone (free and total); 2. Serum Prolactin (done during follicular phase); 3. Serum FSH and LH; 4. Fasting Lipid Profile; 5. Thyroid profile; and 6 . Ultrasound abdomen. Early morning samples are preferred. Other hormonal treatments such as oral contraceptives should be terminated and stopped 1 month before laboratory investigations to avoid false results. Other hormonal treatments such as oral contraceptives should be terminated and stopped 1 month before laboratory investigations to avoid false results.

\section{Patient Evaluation}

A special proforma was prepared to include all the details including age, sex and occupation. Detailed history was also taken with the onset, duration and grading of acne. Detailed examination was carried out in all the cases to find out the precise distribution and morphology of the lesions and to detect if any associated thyroid disorder or hypertriglyceridaemia or PCOS. 


\section{Objectives of the Study}

Assessment of Hormonal levels (Serum free testosterone, DHEA serum, FSH and LH, and serum prolactin levels) in different grades of acne vulgaris.

\section{Study Design}

This is a descriptive study by assessing various hormonal levels in selected patients.

\section{Study Setting}

DVL Department, Andhra Medical College affiliated to King George Hospital, Visakhapatnam, Andhra Pradesh, India.

\section{RESULTS}

This study was done in 25 female patients who attended the DVL OP, KGH, Visakhapatnam, in our study of 25 female patients.

\begin{tabular}{|c|c|}
\hline In Between the Ages & Number of Patients \\
\hline 15-20 years & 12 patients (48\%) \\
\hline $21-25$ years & 08 patients (32\%) \\
\hline $26-30$ years & 03 patients (12\%) \\
\hline 31-35 years & 02 patients (08\%) \\
\hline $\begin{array}{c}\text { Table 1. Out of 25 Patients, Age Distribution among the } \\
\text { Patients with Acne Vulgaris }\end{array}$
\end{tabular}

\begin{tabular}{|c|c|}
\hline Staging of Acne & Number of Patients \\
\hline Severe & 10 patients (40\%) \\
\hline Moderate & 12 patients (48\%) \\
\hline Very Severe & 01 patients (04\%) \\
\hline Mild & 02 patients (08\%) \\
\hline Table 2. Among 25 Patients
\end{tabular}

\begin{tabular}{|c|c|}
\hline $\begin{array}{c}\text { With Associated } \\
\text { Abnormality }\end{array}$ & Number of Patients \\
\hline Hypertriglyceridaemia & 14 patients (56\%) \\
\hline PCOS & 03 patients (12\%) \\
\hline Virilisation features & 01 patient (4\%) \\
\hline Obesity & 02 patients (8\%) \\
\hline \multicolumn{2}{|c|}{ Table 3. Out of 25 Patients } \\
\hline
\end{tabular}

\begin{tabular}{|c|c|c|c|c|c|}
\hline $\begin{array}{c}\text { Stag } \\
\text { ing } \\
\text { of } \\
\text { Acne }\end{array}$ & $\begin{array}{c}\text { No. of } \\
\text { Patients }\end{array}$ & $\begin{array}{c}\text { S. free } \\
\text { Testo- } \\
\text { sterone } \\
\text { Levels } \\
\text { Elevated }\end{array}$ & $\begin{array}{c}\text { S. DHEA } \\
\text { Levels }\end{array}$ & $\begin{array}{c}\text { S. FSH } \\
\text { and } \\
\text { LH } \\
\text { Levels }\end{array}$ & $\begin{array}{c}\text { S. Pro- } \\
\text { lactin } \\
\text { Levels }\end{array}$ \\
\hline Mild & $\begin{array}{c}04 \\
(16 \%)\end{array}$ & $\begin{array}{c}07 \\
(28 \%)\end{array}$ & $06(24 \%)$ & - & - \\
\hline $\begin{array}{c}\text { Moder } \\
\text { ate }\end{array}$ & $\begin{array}{c}12 \\
(48 \%)\end{array}$ & $\begin{array}{c}10 \\
(40 \%)\end{array}$ & $09(36 \%)$ & - & - \\
\hline $\begin{array}{c}\text { Severe } \\
04 \\
(16 \%)\end{array}$ & $\begin{array}{c}05 \\
(20 \%)\end{array}$ & $07(28 \%)$ & - & - \\
\hline $\begin{array}{c}\text { Very } \\
\text { Severe }\end{array}$ & $\begin{array}{c}05 \\
(20 \%)\end{array}$ & $\begin{array}{c}03 \\
(12 \%)\end{array}$ & $03(12 \%)$ & - & - \\
\hline \multicolumn{7}{|c|}{$\begin{array}{l}\text { Table 4. Finally, Hormonal Levels in various Stages of } \\
\text { Acne Vulgaris in 25 Selected Patients are as Follows }\end{array}$} \\
\hline
\end{tabular}

\section{DISCUSSION}

Hyperandrogenism should be considered in the female patient whose acne is severe, sudden in its onset or associated with hirsutism or irregular menstrual periods. The patient should be asked about the frequency and character of her menstrual periods and whether her acne flares with changes in her menstrual cycle. A complete medication history is important, as some medications can cause an abrupt onset of a monomorphous acneiform eruption. Druginduced acne may be caused by: anabolic steroids, corticosteroids, corticotropin, phenytoin, lithium, isoniazid, vitamin B complexes, halogenated compounds and certain chemotherapy medications, particularly with epidermal growth factor receptor (EGFR) inhibitors.

The laboratory workup should include measurement of serum DHEAS, total testosterone and free testosterone. Additional tests to consider include the luteinising hormone (LH) to follicle-stimulating hormone (FSH) ratio with values of DHEAS in the range of $4,000-8,000 \mathrm{ng} / \mathrm{mL}$. An ovarian source of excess androgens can be suspected in cases where the serum total testosterone is $150 \mathrm{ng} / \mathrm{dL}$. Serum total testosterone in the range of $150-200 \mathrm{ng} / \mathrm{dL}$ or an increased LH/ FSH ratio (2.0) can be found in cases of polycystic ovary disease.

In our study out of 25 patients, most of the patients with or without hormonal abnormalities along with PCOS and elevated hypertriglyceridaemia were in the age group between 15 - 20 years with moderate grade of acne. So, Hormonal therapy is effective in acne despite elevated androgen levels or not. It is frequently used as a combination and not a stand-alone therapy. It can be synergistically combined with antibiotics, benzoyl peroxide, azelaic acid and even retinoids.

\section{CONCLUSION}

Thus, Hormonal evaluation should not be a last option in treating acne vulgaris and is mandatory not only for more resistant acne cases and for those who fail to respond to conventional therapies, but it also should be done in the beginning even in mild degrees of acne to prevent acne scarring.

\section{REFERENCES}

[1] Suh DH, Kwon HH. What's new in the physiopathology of acne? Br J Dermatol 2015;172(Suppl 1):13-9.

[2] Gollnick HP, Dreno B. Pathophysiology and management of acne. J Eur Acad Dermatol Venereol 2015;29(Suppl 4):1-2.

[3] Lai JJ, Chang P, Lai KP, et al. The role of androgen and androgen receptor in the skin-related disorders. Arch Dermatol Res 2012;304(7):499-510.

[4] Balachandrudu B, Niveditadevi V, Rani TP. Hormonal pathogenesis of acne - simplified. Int J Sci Stu 2015;3(1):183-5.

[5] Jeremy AH, Holland DB, Roberts SG, et al. Inflammatory events are involved in acne lesion initiation. J Invest Dermatol 2003;121(1):20-7.

[6] Kim J, Ochoa MT, Krutzik SR, et al. Activation of tolllike receptor 2 in acne triggers inflammatory cytokine responses. J Immunol 2002;169(3):1535-41. 